\title{
Development of Learning Materials Integrated of Social Aritmetic and Accounting
}

M. Anang Tauflk ${ }^{{ }^{*}}$, Mulyoto Mulyoto ${ }^{2}$, Sunardi Sunard ${ }^{3}$, Nunuk Suryani ${ }^{4}$

${ }_{1}^{1}$ Postgraduate Program, Science Education Department, Sebelas Maret University Surakarta, Indonesia 2,3,4 Faculty of Teacher Training and Education Sebelas Maret University, Surakarta, Indonesia e-mail: anangtaufik59@yahoo.co.id ${ }^{1}$, profmulyoto@gmail.com² ${ }^{2}$, nardi ip@uns.ac.id ${ }^{3}$, nunuksuryani@fkip.uns.ac.id ${ }^{4}$

\begin{abstract}
The development of integrated learning materials of social arithmetic and accounting was carried out with the aim of making prototypes of learning materials that integrated social arithmetic and accounting. The development combines social arithmetic material as a calculation process and accounting for the preparation of financial statements. This development uses the ADDIE model. The test of the effectiveness of learning materials as a result of the development was carried out by experimental research using posttest group design. The research subjects were students of Middle School 2 Gondang Bojonegoro East Java class VIII $A$ as the experimental class and class VIII $B$ as the control class. The research subjects consisted of 56 students. 28 students in the experimental class, 28 in the control class. The results of the study show that the learning materials developed are feasible and effective to be used in learning integrated social arithmetic and accounting. The results also showed that there were differences in student learning outcomes in the experimental class and the control class. This can be seen from the value of the average posttest in the experimental class is 95.89 in the control class is 87.67 so that the difference is 8.22 .
\end{abstract}

Keywords: Social Arithmetic, Learning Materials, ADDIE

\section{Introduction}

The learning process is a communication process and takes place in a system, so the learning media occupies a fairly important position as one component of the learning system. Without media, communication will not occur and the learning process as a communication process will not be able to take place optimally. Learning media is an integral component of learning systems (Gagne, 1989; Miarso, 2011; Smaldino, 2008). Types of learning media include: Visual media: graphics, diagrams, charts, charts, posters, cartoons, comics; Audial media: radio, tape recorder, language laboratory, and the like; projected still media: slides; over head projektor (OHP), in focus and the like; projected motion media: film, television, video (VCD, DVD, VTR), computers and the like.

In the learning process educators are also tasked with creating a pleasant learning environment and putting aside threats. One way to make learning fun is to use fun teaching materials too, namely teaching materials that can make students feel interested and happy to learn the teaching material (Prastowo, 2012).

Learning Materials an important role in learning (Nurliawati et.al., 2017; Nurjaya, 2012). Learning materials contain important information (Arsanti, 2018). Learning materials are a collection of information, materials, and texts as guiding materials for competencies to be mastered (Prastowo, 2012; Kantun \& Budiawati, 2015). Learning materials as guides for achieving competence are prepared by taking into account the basic competencies to be learned. The function of learning materials can be divided into two, namely functions for teachers and students (Prastowo, 2012).

Mathematics subjects have the function of developing students' ability to solve problems (Abubakar, 2016). Mathematical learning develops the ability to think logically, analytically, critically, and creatively (Sumarmo et.al., 2012; Jayanti \& Wiratomo, 2017). One material that can be used to develop mathematical abilities is social arithmetic (Abubakar,

\footnotetext{
${ }^{*}$ Corresponding author.

Received 13 May 2019; Accepted 18 July 2019; Available online 01 December 2020

(C) 2020 JPI. All Rights Reserved
}

Jurnal Pendidikan Indonesia (JPI) | 675 
2016; Solaikah, Afifah \& Suroto, 2013). One of the social arithmetic materials in mathematics is related to accounting on the subject of financial statements. In this regard, it is necessary to integrate social arithmetic and accounting teaching materials.

A preliminary study was conducted to determine the enthusiasm of students towards mathematics learning materials. Preliminary studies were also conducted to determine the use of innovative learning materials. Preliminary studies were conducted in Gondang 2 Public Middle School, Cotton 1 Public Middle School, Bojonegoro 1 Public Middle School, Tuban 1 Public Middle School, 1 Rengel Public Middle School, Soko 1 Public Middle School in East Java. The data from the preliminary study are as follows: 1) mathematics learning material models that are integrated with social arithmetic in circulation are generally not available even though the curriculum has undergone many changes; 2) material presenters tend to use the lecture method rarely inviting students to learn in nature / contextual; 3) the results of the questionnaire of student attitudes toward mathematics in this case the interest in the teaching material of the study sample was $65.53 \%$, from 92 respondents. The average teacher in teaching uses instructional media innovation materials in the study sample $67.73 \%$ of the 12 respondents in Bojonegoro Regency. The average student attitudes towards the interest of mathematics teaching materials in the study sample were $57.77 \%$ of the 90 respondents, the average teacher in teaching used $68.98 \%$ teaching material innovation media from 12 respondents in the study sample in Tuban Regency.

This is an indicator that students experience learning difficulties. The attitude of interest in teaching materials greatly influences learning interest and influences the ability to capture during the learning process. Students experience learning difficulties if students cannot reach the specified instructional goals (Mulyati, 2010). Teachers still rarely develop their learning innovations and the development of teaching materials used. Learning can be said to be successful if the learning is able to help students achieve the desired competencies (Pribadi, 2010). There are several indicators that can be used to determine the success of the learning process that is effective, efficient, and interesting. Learning needs to be created into an interesting event in order to be able to increase students' interest and learning motivation so an educator needs to design a learning process.

The process of designing learning activities is called the term learning system design (Basri, 2013; Fhathulloh \& Nurhayati, 2017). In the design of learning systems there are media in the form of teaching materials as a tool to facilitate the achievement of learning objectives, while learning resources are all things that contain messages that must be studied in accordance with the subject matter. Determination of media and learning resources must be in accordance with the characteristics of students and regional characteristics (Sanjaya, 2010).

The development of this material aims to provide students with basic management skills and the ability to solve social problems related to arithmetic and accounting that are able to demonstrate mathematical principles in their application to everyday life. Therefore, there must be various material development efforts (Setyosari, 2010).

\section{Method}

The development of integrated learning materials of social arithmetic and accounting is done by research and development. The stages of research and development use development steps developed by (Gall \& Borg, 2007) which made modifications adjusting to needs. The development steps are as follows: research and information gathering, planning, developing initial products, initial field tests, product revisions, expanded trials, final product revisions, dissemination. The initial product development process uses the ADDIE model.

The choice of this model is based on the consideration that the model developed is systematically based on the theoretical foundation of learning design. This model is arranged programmatically with sequences of activities that are systematic in an effort to solve learning problems, especially the problem of the availability of learning resources that are in accordance with the needs and characteristics of students. This ADDIE model shows the basic stages of learning system design that are simple and easy to learn (Pribadi, 2009). 
Models can mean graphical displays, regular and systematic work procedures and contain explanatory or explanatory thoughts (Salma, 2007). Learning models are planning or patterns used as guidelines for planning classroom learning including tutorial learning (Joyce \& Coulhpun, 2011). Learning can be modeled based on procedures in implementing learning according to the model chosen to develop learning in this case one can choose a particular design including the integration model.

The ADDIE model shows the basic stages of learning system design that are simple and easy to learn (Pribadi, 2009; Molenda, 2015). ADDIE models have steps in analysis, design, develop, implement, and evaluate (Cheung, 2016; Molenda, 2015; Hess \& Greer, 2016). Each step in the ADDIE model is as follows: an analysis, the step of analysis includes identifying the need to determine the problem and the right solution. This step is also the stage of determining student competence. Analyze steps to determine the abilities or competencies needed by students to improve their performance or learning achievement. Analysis activities do: 1) identification of learning objectives / general competencies that are appropriate to the problems that occur from learning activities by using existing teaching materials where arithmetic, accounting are taught separately; 2) analyzing students and the context of the needs of integrated mathematics teaching materials between social arithmetic and accounting in interrelated competencies.

Design phase. This stage is to design specific competencies, methods, teaching materials, and learning strategies. Design is focused on the design to find alternative solutions to the learning problems faced. Activities at this stage design: 1) special competencies, 2) methods, 3) teaching material, 4) formulation of specific learning objectives, 5) designing formative evaluations, 6) designing questionnaires for respondents.

Development stage. Done by developing teaching materials that will be used in the learning program. This step includes activities: 1) making, modifying teaching materials on material that has a related theme and a learning approach model to achieve predetermined learning goals; 2) adjusting the procurement of teaching materials with specific objectives (learning outcomes) that have been formulated by the author or the design of the learning program in the design step.

Implementation stage. At this stage implementing the learning program by applying the design or specification of the learning program. Questionnaires are used to obtain qualitative data from the feasibility of products that are made so as a reference in product revisions. Implementation in the field by guiding students to achieve learning objectives or competencies developed. Guarantee the occurrence of problem solving or solutions to overcome the gap in student learning outcomes from the model applied. Evaluation stage. At this stage, evaluating the implementation of learning programs and evaluating learning outcomes related to the products developed is carried out.

Learning materials resulting from development are validated constructively by experts and practitioners. The expert consists of learning technology experts, media experts, mathematics learning experts, accounting experts, and expert learning models. The practitioner consisted of education practitioners. The validation instrument was developed by referring to the components as presented in Table 1.

Table 1. Grid of Validation Instruments

\begin{tabular}{|c|c|c|}
\hline No & Component & Description \\
\hline 1 & Model identity & $\begin{array}{l}\text { To find out whether the identity of the model has } \\
\text { provided the necessary description }\end{array}$ \\
\hline 2 & Objective & $\begin{array}{l}\text { Explain whether the objectives of the development } \\
\text { material are able to reach the goal }\end{array}$ \\
\hline 3 & Learning materials & $\begin{array}{l}\text { Assess whether the teaching materials in substance } \\
\text { the subject matter are in accordance with the } \\
\text { competencies to be achieved }\end{array}$ \\
\hline 4 & Design of Learning Activities & $\begin{array}{l}\text { Ensure whether learning activities are well designed } \\
\text { and can accommodate student-centered learning }\end{array}$ \\
\hline
\end{tabular}




\begin{tabular}{lll}
\hline No & Component & Description \\
\hline 5 & Learning Assessment & $\begin{array}{l}\text { Ensuring the learning assessment process has } \\
\text { accommodated the assessment to be carried out }\end{array}$ \\
\hline
\end{tabular}

The final product in the form of integrated social arithmetic teaching materials is tested for effectiveness. The stage of testing the effectiveness of the model was done by quasi-experimental research type pre test and post test experimental group and control group. The schematic description of the study is presented in Table 2.

Table 2. Research Design Test for Effectiveness

\begin{tabular}{lccc}
\hline Group & Pretes & Teatment & Posttes \\
\hline Experiment & $\mathrm{O}_{1}$ & $\mathrm{X}$ & $\mathrm{O}_{2}$ \\
control & $\mathrm{O}_{3}$ & $\mathrm{Y}$ & $\mathrm{O}_{4}$ \\
\hline
\end{tabular}

The population used in the effectiveness test research was the eighth-grade students of Gondang Bojonegoro State Junior High School 2 in East Java with a total of 56 students consisting of two study groups. Each study group consisted of 28 students. The sampling technique is done by simple random sampling where sampling is done randomly regardless of the strata that exist in the population.

Data was collected from the results of the evaluation stage to analyze the effectiveness of the model developed from the posttest results of students in the control class and the experimental class. Limited trials include sample testing. Individual evaluation, conducted by researchers with three people individually. The students chosen are those that represent the criteria referred to by giving a pretest to find out the students' initial abilities. The application of integrated social arithmetic accounting to respondents and posttest after application to determine differences in initial abilities before being applied and after application.

Expanded trials include classics per location of the study sample with development with students of one class which are used as sample classes. This evaluation does not include students who have participated in individual evaluations. The purpose of this evaluation is to identify shortcomings of learning activities after being revised based on individual evaluations. Expected input is not only about learning material, but also the learning process by giving a pretest to find out the initial abilities of classical students. The use of social arithmetic teaching materials developed and posttested to determine differences in initial abilities before using the results of the development of social arithmetic learning materials with abilities after using the results of the development of integrated accounting social arithmetic learning materials.

The technique used for analyzing the model of integrated accounting mathematics learning materials developed includes descriptive statistical analysis techniques. To find out the normality and homogeneity of the data by analyzing the results of the pretest experimental class with the pretest of the control class using SPSS. To process the data in the form of the results of the pretest and posttes of the experimental class with the t-paired test, so that it is known the effectiveness of the learning material products developed.

\section{Results and Discussion}

\section{Description of Development of Learning Materials}

Development of learning materials is carried out by using the ADDIE model. The results of each development stage are as follows.

Analysis of the results of the preliminary study obtained data on the needs of integrated accounting arithmetic learning materials from existing learning materials so that the competencies that students needed to improve learning outcomes were focused on related competencies in social arithmetic related to accounting. Exemplified as the relationship between determining the difference between the purchase and sale price that generates profit, the loss resulting from the calculation is included in the accounting report. 
The creation of integrated learning materials of social arithmetic and accounting as development material that has the usefulness of the problem that must be overcome is the problem of disparity in students. This difference includes the abilities that already have and the abilities that students must have from the model that will be applied. Development results. The realization of new development products that include programs and learning materials that will be used in the learning program. From the results of modifying learning materials and learning approach models to achieve predetermined learning goals. The integration of themes in social arithmetic material: taxes, sales, purchases, profit, loss, discounts, single interest, reporting in balance sheet form. This becomes one theme with the development of material consisting of concepts, factual, procedural, metacognitive from the results of consultations to experts and practitioners.

In the design phase development of learning materials will be used to be used in the learning program. Activities carried out at the development stage are: 1) making, modifying learning materials and learning approach models to achieve predetermined learning goals; 2) adjusting the procurement of learning materials with specific objectives that have been formulated by the author or the design of the learning program in the design step; 3 ) implementing development of assessment instruments, learning strategies, and developing and selecting learning materials.

In this activity, combining themes in social arithmetic material: sales, purchases, profit, loss, discounts, single interest, and economy in taxes, accounting for reporting in balance sheet form. This becomes one theme with the authors developing on the material consisting of concepts, factual, procedural, metacognitive. The material concept contains the basic concepts of matter. Factual contains facts that are often encountered by students in everyday life. The Procedural Section contains the completion of several examples in life that are completed systematically with mathematical completion steps. The metacognitive section was developed by making accounting reports from the results of mathematical solutions to procedures. This development helps train students in answering everyday problems with basic mathematical concepts and making activity reports according to the inclusion in the activity report.

Learning materials from the development results are tested in a valid and material manner. Construct validation is carried out by experts. Development of this teaching material has been consulted with experts 1 learning technology percentage of $78.12 \%$ from 26 questionnaire items and experts 2 teaching material materials amounting to $75.00 \%$ of the 26 items questionnaire given, the average of two experts is $76.56 \%$ which can be said that this product is worth testing. Learning technology experts and instructional materials provide suggestions: 1) added instructions for learning in learning materials, to give examples of tables and are worthy of testing. 2) this model is feasible to be tested in schools that are still implementing KTSP or by providing the power of the steps in the CTL with a scientific approach if applied to schools that use the 2013 curriculum.

The development of integrated mathematics learning materials was also consulted with practitioner education practitioner 1 with a percentage of $84.37 \%$ of the 26 questionnaire items and practitioner 2 amounting to $86.87 \%$ of the 26 questionnaire items given and giving practitioner advice 1: these teaching materials could be used by students, practitioner 2: generally can be used. The results of the feasibility test and readability of the device are in the form of a Likert scale which includes the feasibility test of the device. From some of the data obtained above, the interpretation is between $61 \%-80 \%$, so it can be said that this integrated mathematics teaching material is feasible to be used for testing on research samples in selected regions.

Implementation of the application of learning by applying product design or specifications to topics related to daily life and completed as examples that have been presented in the integrated mathematical material developed. Results of evaluation. Evaluation of learning programs and evaluation of learning outcomes. Evaluation is a process carried out to provide value to the learning program. Evaluation with formative evaluation and clarification of the target competency by comparing the learning that has been 
achieved by students with the learning objectives that have been previously formulated. This evaluation is an authentic assessment.

Teaching materials the results of the development were tested limited and expanded. The results of the trial are limited and extended as follows: Limited trial results. In this study includes a sample location test. Individual evaluation, conducted by researchers with three people individually. The students chosen are those that represent the criteria referred to by giving a pretest to find out the students' initial abilities. Obtained an average value of 20,319.

In this study includes classics per sample location of research by developers with students of one class which is used as sample classes. This evaluation does not include students who have participated in individual evaluations. The purpose of this evaluation is to identify shortcomings of learning activities after being revised based on individual evaluations. Expected input is not only about instructional materials, but also the learning process by giving a pre test to find out the initial abilities of classical students. Expanded test data obtained $=76,028$.

Results of Development of social arithmetic learning materials integrated with accounting. The connection of this material becomes one theme. Social arithmetic which is a step-in solving problems is reported in accounting. Arithmetic is combined with accounting as a continuation after the results of the settlement calculation are known. Posting into a simple balance sheet form for accounting reports from arithmetic. The ability of students to post journals is a new experience of students and field data is obtained by students able to do. Students are able to solve social problems from arithmetic problems with accounting reports. The completion of the settlement process is done mathematically in the calculation step after obtaining the results and then entering it into the appropriate post for reporting.

\section{Results of Model and Learning Materials Validation}

The instructional materials of the results of the development before the expanded trial were carried out construct validation by experts and practitioners. The validation results on the model identity component shown in Table 3.

Table 3. Score assessment of model identity components

\begin{tabular}{clcc}
\hline \multirow{2}{*}{ Component } & \multicolumn{1}{c}{ Criteria } & \multicolumn{2}{c}{ Average score } \\
\cline { 3 - 4 } & & Expert & Practitioner \\
\hline \multirow{3}{*}{ Model } & Showing model identity clearly & 4 & 4 \\
Identity & Coherent and realistic standards of competence & 4 & 4 \\
& and competency are achieved & 4 & 4 \\
& Easy to understand learning instructions & 4 & 4 \\
& Clarity of steps in lesson plan & 4 & 4 \\
\hline
\end{tabular}

Based on Table 3, it can be concluded that the model identity is clear and can be properly identified. The standards of competence and basic competencies contained in teaching materials can be identified and in accordance with the applicable laws and regulations regarding content standards. According to experts and practitioners, learning instructions in teaching materials are easy to understand. Experts and practitioners argue that teaching materials can be used by teachers and students easily because the learning instructions are complete. Indonesian language used in teaching materials is good. the use of standard and correct Indonesian has been applied.

Validation in the components of learning objectives is carried out to ensure that the learning objectives listed in the teaching material are appropriate. The objective component validation results shown in Table 4. Based on Table 4, it can be concluded that the objective component is said to be good and the goal is clear. The formulation of goals is simple, interesting, and can explain the objectives to be achieved. Based on the opinions of experts and practitioners, it can be concluded that the objectives listed in the teaching material can 
explain the objectives to be achieved. The use of simple and interesting sentences can lead to student motivation. Students can be motivated to achieve learning goals in stages.

Table 4. Score assessment of the objective component

\begin{tabular}{llcc}
\hline \multirow{2}{*}{ Component } & \multicolumn{1}{c}{ Criteria } & \multicolumn{2}{c}{ Average score } \\
\cline { 3 - 4 } & & Expert & Expert \\
\hline \multirow{2}{*}{ Objective } & Formulate simple and interesting goals & 4 & 4 \\
& xplain the purpose to be achieved & 4 & 4 \\
& Motivating students to achieve goals gradually & 4 & 4 \\
\hline
\end{tabular}

The instructional materials developed are quite good. three criteria, which are the presentation of supporting images, variations in the presentation of information, and the organization of material integration. In line with the findings of (Lestari \& Hartati, 2017), the use of images greatly impacts the mastery of teaching material. A good supporting image is a picture that can clarify students in understanding teaching material. The title of teaching material according to experts and practitioners has been able to show the purpose of developing teaching materials.

Table 5. Score assessment of the objective component

\begin{tabular}{clcc}
\hline \multirow{2}{*}{ Component } & \multicolumn{1}{c}{ Criteria } & \multicolumn{2}{c}{ Average score } \\
\cline { 2 - 4 } & $\begin{array}{l}\text { Expert } \\
\text { The title matches the basic competencies that must } \\
\text { be achieved } \\
\text { The order of sub topics / material in accordance with } \\
\text { basic competencies and scientific systematics } \\
\text { Material coherence with the objectives to be }\end{array}$ & 4 & 4 \\
$\begin{array}{l}\text { achieved } \\
\text { Presentation of examples in simple, understandable }\end{array}$ & 4 & 4 \\
Learning & $\begin{array}{l}\text { ways that support the material } \\
\text { Using language that is easy to understand / }\end{array}$ & 4 & 4 \\
$\begin{array}{l}\text { communicative } \\
\text { Presentation of supporting images in clarifying the } \\
\text { message }\end{array}$ & 3 & 3 \\
$\begin{array}{l}\text { Variation in information presentation } \\
\text { Application of strategies for organizing material for } \\
\text { integration }\end{array}$ & 3 & 3 \\
$\begin{array}{l}\text { The accuracy of the application of learning strategies } \\
\text { (learning according to CTL steps) }\end{array}$ & 4 & 3 \\
\hline
\end{tabular}

An important part in developing teaching materials is the design of learning activities. Properly designed learning activities can support the achievement of goals. Activities are designed according to the syntax of the learning model used. In the opinion of experts and practitioners, the design of learning activities is in a good category. The teacher has been designed as a partner and facilitator in learning. The role of the teacher who is a partner and facilitator will have an impact on the student-centered learning process. Teacher and student interaction is very important in learning. Good interactions between teachers and students can improve the achievement of learning objectives. Teaching materials developed according to experts and practitioners have provided interaction services between teachers and students well. Table 6 describes the results of the assessment of teaching materials in the components of learning activities. 
Table 6. Scoring assessment of design components of learning activities

\begin{tabular}{llcc}
\hline \multirow{2}{*}{ Component } & \multicolumn{1}{c}{ Criteria } & \multicolumn{2}{c}{ Average score } \\
\cline { 3 - 4 } & & Expert & Expert \\
\hline \multirow{2}{*}{$\begin{array}{l}\text { Design of } \\
\text { Learning }\end{array}$} & Provides interactive services between teachers and & 4 & 4 \\
Activities & students & 4 & 4 \\
& $\begin{array}{l}\text { Organizing student learning in groups } \\
\text { Providing opportunities for teacher professional }\end{array}$ & 4 & 4 \\
& development & 4 & 4 \\
\hline
\end{tabular}

The component of assessment of learning in teaching materials in general is good. Scores given by experts and practitioners are average 4. Teaching materials have accommodated assessments in accordance with the competencies taught. The assessment has accommodated competency test tests, so that the competencies to be achieved have been monitored through the assessment process. The valuation technique used is simple and easy to apply. The ease of applying assessment techniques has an impact on the validity and reliability of the assessment. The assessment process can assess what should be assessed. The focus of the teaching material developed is on the integration between social arithmetic and accounting. In order for the impact of the use of teaching materials to be good, a focus on integrated learning outcomes is needed. According to experts and practitioners, the assessment process has accommodated integration.

Table 7. Scores for assessment of learning assessment components

\begin{tabular}{clcc}
\hline \multirow{2}{*}{ Component } & \multicolumn{1}{c}{ Criteria } & \multicolumn{2}{c}{ Average score } \\
\cline { 2 - 4 } & & Expert & Expert \\
\hline \multirow{3}{*}{ Learning } & Assessment in accordance with competence & 4 & 4 \\
Assessment & Clarity of assessment of learning outcomes through & 4 & 4 \\
& competency test & 4 & 4 \\
& Using assessment techniques that are easy to apply & 4 & 4 \\
\cline { 2 - 4 } & Focusing learning outcomes in an integrated manner & 4 & \\
\hline
\end{tabular}

Based on the assessment of each component of the teaching material, it can be concluded that the teaching material developed is feasible to use in the next step. Repairs are carried out in accordance with the notes and results of discussions with experts and practitioners.

\section{The results of the pretest and posttest control class $t$ tests}

The results of this test are presented in Table 8.

Table 8. Test Results t-Paired control class

\begin{tabular}{|c|c|c|c|c|c|c|}
\hline & $\mathbf{t}$ & & $\begin{array}{l}\text { Sig. (2- } \\
\text { tailed) }\end{array}$ & Mean Difference & Lower & Upper \\
\hline pre1 & 20.800 & 27 & .000 & 29.46429 & 26.5578 & 32.3708 \\
\hline post1 & 48.964 & 27 & .000 & 87.67857 & 84.0044 & 91.3527 \\
\hline
\end{tabular}

Based on Table 8 , in the control class with the number of respondents 28 students used social arithmetic material that had not been developed and obtained the lowest pretest value of 26.55 while the highest value was 32.37. The lowest posttes value is 84.00 and the highest is 91.35 . The average pretest is 29.46 and posttest is 87.67 so there is an increase of 58.21 from the average ability of students in the control class. 


\section{The results of the pretest and posttest experimental class}

Table 9. Test Results t-Paired Experimental Classes

\begin{tabular}{lcccccc}
\hline & $\mathbf{t}$ & $\mathbf{d f}$ & Sig. (2-tailed) & $\begin{array}{c}\text { Mean } \\
\text { Difference }\end{array}$ & Lower & Upper \\
\cline { 2 - 7 } pre2 & 20.319 & 27 & .000 & 31.07143 & 27.9338 & 34.2091 \\
pos2 & 76.028 & 27 & .000 & 95.89286 & 93.3049 & 98.4808 \\
\hline
\end{tabular}

From Table 9 it is described that in the experimental class using developed social arithmetic material combined with accounting, the lowest pretest scores were obtained 27.93 and the highest value was 34.20. The posttest value in the experimental class obtained the lowest value of 93.90 highest 98.48. The average pretest value was 31.07 and the posttes average score was 95.89 so that there was an increase of 64.82 from the initial ability in the experimental class.

\section{T-independent test results for model effectiveness}

To determine the effectiveness of the model, the independent t-test and the results of this study shown in Table 10.

Table 10: T-independent test results

\begin{tabular}{|c|c|c|c|c|c|c|}
\hline & $F$ & Sig. & $\mathbf{t}$ & df & $\begin{array}{l}\text { Sig. (2- } \\
\text { tailed) }\end{array}$ & $\begin{array}{c}\text { Mean } \\
\text { Difference }\end{array}$ \\
\hline $\begin{array}{l}\text { post Equal variances } \\
\text { assumed }\end{array}$ & 10.226 & .002 & 3.750 & 54 & .000 & 8.21429 \\
\hline $\begin{array}{l}\text { Equal variances not } \\
\text { assumed }\end{array}$ & & & 3.750 & 48.499 & .000 & 8.21429 \\
\hline
\end{tabular}

Based on the results of the independent t-test it was found that: there was a difference in the results of the posttest between the control class and the experimental class of 8.22. This difference proves that material development is more meaningful and better than the material that has been taking place in learning.

The development of teaching materials is very helpful for students in completing arithmetic questions, especially related material in daily life. Integrated social arithmetic teaching materials accounting also adds insight to students in posting financial statements. This improves students' skills in the post process and is familiar with the preparation of financial statements. There is a significant increase in learning outcomes in student posttimes accumulated from the data in all study samples obtained data $95.85 \%$ of students were able to answer the questions tested and $4.15 \%$ had not been able to answer the questions tested. This development material adds insight and references to students in the teaching and learning process. This material has good effectiveness so that it can be used for additional teaching materials and completing material completion in social arithmetic and preparation into accounting reports.

Increasing the learning outcomes of mathematics in integrated social arithmetic accounting can not be separated from the ongoing learning process. The learning process carried out using instructional materials as a result of development shows an increase in student activity. Student activities that take place during learning encourage the effectiveness of material absorption, which is indicated by better learning outcomes (Hasnawati \& Ardin, 2010; Mufarizuddin, 2018). In addition, during the learning process students are greatly helped by integrated teaching materials. Good teaching materials encourage students' enthusiasm in learning (Muchyidin, \& Winarso, 2017; Qomariah \& Sudiarditha, 2016). 


\section{Conclusions}

Based on the results of the research and discussion, it can be concluded as follows: In the application of the social arithmetic development model integrated with accounting, the average student can post to the report, some of them still do not understand the product being developed. There is an increase in the initial ability of students at the initial pretest after applying integrated social arithmetic accounting on student post times accumulated from the data in all study samples. Most students are able to answer the questions tested so that the developed models can be tested for effectiveness and the final results that are effectively used by students as additional reference material and also educators to carry out learning with additional learning resources as supporters of existing social arithmetic material.

\section{Reference}

Abubakar, W. (2016). Analytical Problem Solving Skills At Social Arithmetic In Project Based Learning In Grade 3 SMP Islam Athirah Bukit Baruga. Daya Matematis: Jurnal Inovasi Pendidikan Matematika, 4(3), 380-392. https://doi.org/10.26858/jds.v4i3.2930

Aladejana, F., \& Aderibigbe, O. (2007). Science Laboratory Environment And Academic Performance. Journal of Science Education and Technology, 16(6), 500-506. https://doi.org/10.1007/s10956-007-9072-4

Basri, B. (2017). Signifikansi Desain Pembelajaran dalam Menunjang Kesuksesan Mengajar. Nizham Journal of Islamic Studies, 1(2), 190-203. https://www.learning.metrouniv.ac.id/index.php/nizham/article/view/855

Budiawati, Y. S. R., \& Kantun, S. (2016). Analisis tingkat kelayakan bahan ajar ekonomi yang digunakan oleh guru di SMA Negeri 4 Jember. Jurnal Pendidikan Ekonomi: Jurnal IImiah IImu Pendidikan, IImu Ekonomi dan IImu Sosial, 9(1), 129-146. https://jurnal.unej.ac.id/index.php/JPE/article/view/3384

Cheung, L. (2016). Using the ADDIE Model of Instructional Design to Teach Chest Radiograph Interpretation. Journal of Biomedical Education, 16, 1-6. https://doi.org/10.1155/2016/9502572

Fhatulloh, M. R., \& Yusup, M. (2017). Implementasi Guru Dalam Mendesain Proses Pembelajaran PAI. Atthulab: Islamic Religion Teaching and Learning Journal, 2(2), 133-139. https://doi.org/10.15575/ath.v2i2.2790

Gagne, M. (1996). The Conditions of Learning: Training Applications. Harcourt Brace.

Hasnawati, H., \& Ardin, A. (2010). Efektivitas Penerapan Pembelajaran Konstruktivis terhadap Hasil Belajar Matematika. Jurnal Pendidikan Matematika, 1(2), 114-121. https://dx.doi.org/10.36709/jpm.v1i2.1948

Jayanti, M., \& Wiratomo, Y. (2017). Perancangan Media Siap UN Matematika SMP Berbasis Android. SAP (Susunan Artikel Pendidikan), 2(1), 22-32. http://dx.doi.org/10.30998/sap.v2i1.1722

Joyce, B., Weil, M., \& Calhoun, E. (2011). Models of Teaching (Model-Model Pengajaran). Pustaka Pelajar.

Lestari, P. B., \& Hartati, T. W. (2017). Analisis Pengembangan Bahan Ajar Mikrobiologi Berbasis Inkuiry di IKIP Budi Utomo Malang. Bioedukasi: Jurnal Pendidikan Biologi, 10(2), 1-6. https://doi.org/10.20961/bioedukasi-uns.v10i2.11332

Miarso, Y. H. (2011). Menyemai Benih Teknologi. Kencana Prenada Group.

Molenda, M. (2015). In search of the elusive ADDIE model. Performance Improvement, 54(2), 40-42. https://doi.org/10.1002/pfi.21461

Muchyidin, A. (2017). Pengaruh Penggunaan Bahan Ajar Matematika Bersuplemen Komik Terhadap Kemandirian Belajar Siswa. Eduma: Mathematics Education Learning and Teaching, 6(1), 43-51. http://dx.doi.org/10.24235/eduma.v6i1.1667 
Mufarizuddin. (2018). Improving learning outcomes by using think pair share (TPS) cooperative learning model at primary school students. Jurnal Pendidikan Indonesia, 7(2), 77-85. https://doi.org/10.23887/jpi-undiksha.v7i2.10469

Nichols Hess, A., \& Greer, K. (2016). Designing for Engagement: Using the ADDIE Model to Integrate High-Impact Practices Into an Online Information Literacy Course. Communications In Information Literacy, 10(2), 264-282. https://doi.org/10.15760/comminfolit.2016.10.2.27

Nurjaya, G. (2012). Pengembangan bahan ajar metode pembelajaran bahasa dan sastra indonesia berbasis pembelajaran kooperatif jigsaw untuk meningkatkan pemahaman dan kemampuan aplikatif mahasiswa. Jurnal Pendidikan Indonesia, 1(2), 102-111. https://doi.org/10.23887/jpi-undiksha.v1i2.4490

Nurliawati, L., Mujasam, Yusuf, I., \& Widyaningsih, S. W. (2017). Lembar kerja peserta didik (LKPD) berbasis problem solving polya. Jurnal Pendidikan Indonesia, 6(1), 72-81. https://doi.org/10.23887/jpi-undiksha.v6i1.9183

Prastowo, A. (2012). Panduan kreatif membuat bahan ajar inovatif. Diva Press.

Prawiradilaga, D. S. (2009). Prinsip Desain Pembelajaran. Prenada Media Group.

Pribadi, B. A. (2010). Desain sistem pembelajaran. Dian Rakyat.

Qomariah, S. S., \& Sudiarditha, K. R. (2016). Kualitas media pembelajaran, minat belajar, dan hasil belajar siswa: studi pada mata pelajaran ekonomi di kelas X IIS SMA Negeri 12 Jakarta. Jurnal Pendidikan Ekonomi dan Bisnis, 4(1), 33-47. https://doi.org/10.21009/JPEB.004.1.3

Sanjaya, W. (2010). Perencanaan dan Desain Sistem Pembelajaran. Kencana Prenada Group.

Setyosari, P. (2010). Metode Penelitian Pendidikan dan Pengembangan. Kencana.

Smaldino, E. (2008). Instructional Technology And Media For Learning (Teknologi Pembelajaran Dan Media Untuk Belajar). Kencana Prenada Group.

Solaikah, Afifah, D. S., \& Suroto. (2013). Identifikasi kemampuan siswa dalam menyelesaikan soal aritmatika sosial ditinjau dari perbedaan kemampuan matematika. Jurnal Pendidikan Matematika STKIP PGRI Sidoarjo, 1(1), 97-106.

Sumarmo, U., Hidayat, W., Zukarnaen, R., Hamidah, \& Sariningsih, R. (2012). Kemampuan dan disposisi berpikir logis, kritis, dan kreatif matematik (Eksperimen terhadap siswa SMAmenggunakan pembelajaran berbasis masalah dan strategi think-talk-write). Jurnal Pengajaran MIPA, 17(1), 17-33. 